\title{
PENGARUH VOID RATIO DAN PERMEABILITAS BETON TERHADAP KUAT TEKAN BETON POROUS DENGAN RCA
}

\author{
Naila Mahdiana ${ }^{1}$, Eva Arifi $^{2}$, Wisnumurti $^{2}$, Ananda Insan Firdausy $^{2}$ \\ ${ }^{1}$ Mahasiswa / Program Studi Sarjana Teknik Sipil Fakultas Teknik / Universitas Brawijaya \\ ${ }^{2}$ Dosen / Jurusan Teknik Sipil Fakultas Teknik / Universitas Brawijaya \\ Korespondensi: naila.mahdiana16@gmail.com
}

\begin{abstract}
The infrastructure development raises the potential of old building destruction and demolition. This fact will results an environmental damage if construction waste is not being properly utilized. One type of construction waste that can be utilized is concrete waste. To apply sustainable development, concrete waste can be reused and recycled into aggregate in the form of RCA (Recycled Coarse Aggregate). Natural Coarse Aggregates $(N C A)$ and RCA are processed into $0.5-1 \mathrm{~cm}, 1-2 \mathrm{~cm}$, and $0.5-2 \mathrm{~cm}$ sizes and later mixed with cement paste into porous or pervious concrete. Porous concrete is a non-structural concrete which is water-permeable and has large pores. This study aims to determine the effect of RCA on the velue of concrete compressive strength, the most optimal concrete variation, and the influence of void ratio and permeability to the compressive strength of porous concrete. The result reported that $R C A$ affects the compressive strength, it can be proven that any variation of aggregate size, concrete variation with 0\% RCA has the higher value than the $100 \%$ RCA one. The optimum concrete condition is in variation of $50 \%$ RCA at aggregate size $0.5-2 \mathrm{~cm}$. The compressive strength value is $10.211 \mathrm{MPa}$. This is due to the more diverse aggregates affecting the concrete density. The larger the pores of the concrete (void ratio), the permeability value will be higher and the higher void ratio and permeability of concrete, the value of the compressive strength of porous concrete will be lower.
\end{abstract}

Keywords: Concrete waste, RCA, void ratio, permeability, compressive strength

\section{PENDAHULUAN}

Kontribusi limbah kontruksi di Indonesia dalam perkembangannya semakin meningkat. Laju perkembangan infrastruktur yang tinggi berakibat pada intensitas penghancuran bangunan yang semakin besar karena ketidaksesuaian dengan proyek baru yang akan dijalankan. Pengalokasian limbah tersebut juga semakin sulit untuk ditemukan, sebagian digunakan sebagai bahan urugan, dan sebagian lagi dibuang di lahan-lahan terbuka. Pemanfaatan limbah beton juga tidak dimanfaatkan dengan baik. Hal ini akan berdampak buruk terhadap pelestarian lingkungan. Limbah material beton yang dihancurkan dari bangunan yang mutu betonnya tinggi dapat diimplikasikan menjadi agregat baru dengan kualitas yang berbeda dan dapat digunakan sebagai bahan konstruksi kembali.

Sifat beton dengan agregat daur ulang jika dibandingkan dengan beton yang menggunakan agregat natural misalnya kuat tekan menurun sebesar $10 \%$ - 30\% dan kuat tarik lebih rendah tidak lebih dari 10\%. Karena agregat daur ulang mengandung mortar sehingga sifat dari agregat tersebut lebih porous dan absortive daripada agregat alami. Hal ini menunjukkan bahwa agregat daur ulang kasar memiliki tingkat absorbsi antara 5\% sampai 6\% sedangkan agregat daur ulang halus memiliki tingkat absorbs sebesar 9\% sampai 10\%. Sifat tersebut meiliki perbedaan yang signifikan dibandingkan dengan agregat alami yang biasanya memiliki tingkat absorbs sebesar $1 \%$ sampai $2 \%$. [1]

Tujuan dari penelitian ini adalah :

1. Mengetahui pengaruh variasi RCA terhadap kuat tekan beton

2. Mengetahui pengaruh void ratio dan permeabilitas beton porous terhadap kuat tekan beton.

3. Mengatahui komposisi optimal agregat kasar daur ulang sebesar 0\%, 50\%, dan $100 \%$ dengan agregat alam yang sesuai dengan persyaratan mutu beton. 


\section{TINJAUAN PUSTAKA}

\subsection{Beton Porous}

Beton porus atau beton non pasir adalah campuran antara semen, air, dan agregat kasar dengan diameter seragam untuk menghasilkan material yang porus. Beton tersebut memiliki volume rongga yang besar dengan penurunan kekuatan yang masih dapat diterima dan berat sendiri yang ringan. Beton ini memiliki beberapa nama yaitu beton non pasir, beton pervious, dan beton porus [2].

Beton non pasir mempunyai agregat kasar dengan diameter seragam yang terlapis oleh lapisan pasta semen yang tipis sekitar $1,3 \mathrm{~mm}$ [3]. Berdasarkan standar ACI 522R-10 [4] persentase faktor air semen yang paling baik untuk beton berpori pada 0,26 sampai dengan 0,45 . Dimana kondisi tersebut merupakan kondisi yang stabil pada pasta semen, dan lapisan merata pada agregat. Telah ditemukan $0,3 \mathrm{w} / \mathrm{c}$ dengan mix agregat $50 \%$ memiliki hasil yang lebih baik untuk beton porous [5].

\subsection{Agregat}

Beberapa perbedaan penggunaan RCA apabila dibandingkan dengan penggunaan NCA diantaranya adalah :

1. Kuat tekan menurun sebesar $10 \%-30 \%$

2. Kuat Tarik lebih rendah dari $10 \%$

3. Modulus elastisitas menurun sebesar $10 \%$ $40 \%$ tergantung dari sumber agregat kasarnya.

4. Susut lebih besar $20 \%$ - $55 \%$ sedangkan creep lebih kecil hingga 10\%

Berdasarkan hasil studi penilitian, RCA mengandung mortar kurang lebih 25\% hingga $45 \%$, yang berdampak pada berat jenis agregat menjadi lebih kecil, lebih berpori, kekerasannya berkurang, bidang temu (interface) bertambah, dan unsur-unsur kimia agresif lebih mudah masuk dan merusak. Selain itu, terdapat retak mikro pada RCA yang ditimbulkan akibat tumbukan mesin pemecah batu ketika proses produksi agregat daur ulang yang tidak dapat membelah daerah lempengan atau patahan pada NA. Akibat kekangan mortar yang menyelimuti NA maka akan menahan retak yang terjadi.

\subsection{Penelitian Pendahuluan untuk Agregat}

Penelitian pendahuluan merupakan penelitian yang bertujuan untuk mengetahui faktor yang mempengaruhi kualitas beton. Penelitian ini dilakukan pada komponen- komponen material yang mempengaruhi campuran beton seperti RCA (Recycled Coarse Agregate) dan NCA (Normal Coarse Agregate). RCA yang digunakan merupakan hasil dari penghancuran dari beton yang diolah kembali menjadi agregat kasar. Sedangkan NCA merupakan hasil penghancuran batuan alam atau agregat alami yang diambil dari alam. Oleh karena itu, perlu adanya penelitian pendahuluan untuk mengetahui kualitas agregat RCA yang digunakan terhadap NCA. Penelitian pendahuluan ini terdiri dari berat isi agregat, berat jenis, dan penyerapan agregat.

\subsubsection{Pengujian Density Agregat}

Pengujian ini dimaksudkan untuk mengetahui nilai kerapatan dan kepadatan agregat kasar. Density merupakan perbandingan antara massa benda dengan volume benda. Pengujian dilakukan dengan menimbang berat agregat kasar dalam keadaan jenuh dan membaginya dengan volumenya.

Density $(\rho)=\mathrm{Mj} / \mathrm{Vb}$.

Keterangan :

$\mathrm{Mj}=$ Massa jenuh $(\mathrm{kg})$

$\mathrm{Vb}=$ Volume $\left(\mathrm{m}^{3}\right)$

\subsubsection{Analisa Berat Jenis dan Penyerapan} Agregat Kasar ASTM-C33

Berat jenis agregat kasar adalah perbandingan berat agregat kasar dengan berat air suling yang mempunyai volume sama dengan agregat kasar. Dalam merencanakaan campuran beton (Mix Design), salah satu data yang diperlukan diantaranya berat jenis curah, berat jenis kering permukaan air pada agregat kasar.

Penyerapan air pada agregat kasar diperoleh dari perbandinan berat air yang dapat diserap pori terhadap berat agregat kasar kering yang dinyatakaan dalam prosen. Penyerapan air ini berfungsi untuk menentukan besarnya kandungan air dan agregat dalam pembuatan Mix Design, sehingga diperoleh campuran beton yang ideal. Menurut SK - SNI - 15-1990-03, pengerjaan perencanaan beton disebutkan bahwa penyerapan air agregat kasar untuk agregat kasar $\leq 1.63 \%$. Dengan tujuan yaitu :

a. Menetapkan berat jenis curah.

b. Menetapkan berat jenis kering permukaan jenuh.

c. Menetapkan berat jenis semu.

d. Menentukan absorbsi pada agregat kasar. 


\subsection{Sifat-Sifat Beton}

\subsubsection{Kelecakan (Workability)}

Workability atau kelecakan adalah kemudahan dalam mengerjakan beton segar. Guna menguji kelecakan beton segar digunakan uji slump. Semakin besar nilai slump, semakin mudah untuk dikerjakan dan begitu pula sebaliknya semakin kecil nilai slump maka semakin sulit untuk dikerjakan .

\subsubsection{Permeabilitas (Permeability)}

Permeabilitas beton adalah kemudahan beton untuk dapat dilalui air. Jika beton tersebut dapat dilalui air maka, beton tersebut dikatakan permeable. Jika sebaliknya, maka beton tersebut dikatakan impermeable. Maka sifat permeabilitas yang penting pada beton adalah permeabilitas terhadapa air (Sugiharto, 2004). Untuk mengetahui permeabilitas beton maka, dibutuhkan pengujian. Uji permeabilitas terdiri dari dua macam, diantaranya adalah uji aliran (flow test) dan uji penetrasi (penetration test). Uji yang pertama digunakan untuk mengukur permeabilitas beton terhadap air bila ternyata air dapat mengalir melalui sampel beton. Uji penetrasi digunakan jika dalam percobaan permeabilitas tidak ada air yang mengalir melalui sampel. Dari data yang dihasilkan oleh uji permeabilitas ini dapat ditentukan koefisien permeabilitas, suatu angka yang menunjukkan kecepatan rembesan fluida dalam suatu zat.

Untuk pengukuran permeabilitas pada beton pourus dapat menggunakan metode pada ACI-522R. Falling head adalah salah satu metode yang digunakan untuk mengukur permeabilitas air. Gambar 1 menunjukkan gambar susunan uji permeabilias.

Pengukuran permeabilitas ini menggunakan air sebanyak $300 \mathrm{~mm}$ diatas beton. Untuk mengukur permeabilitas, digunakan beton berbentuk silinder dengan ukuran $100 \mathrm{~mm}$ x $200 \mathrm{~mm}$ yang telah dicor. Silinder tersebut dicor pada pipa PVC. Beton diukur permeabilitasnya pada umur 28 hari. Penghitungan permeabilitas beton pourus menggunakan persamaan 1 .

$k=\frac{A_{1} l}{A_{2} t} \log \frac{h_{2}}{h_{1}}$

Dimana,

$$
\begin{array}{ll}
\mathrm{k} & =\text { permeabilitas air }(\mathrm{mm} / \mathrm{s}) \\
\mathrm{A}_{1} & =\text { Luas sample }(\mathrm{mm}) \\
\mathrm{A}_{2} & =\text { Luas alat }(\mathrm{mm}) \\
1 & =\text { panjang sampel }(\mathrm{mm}) \\
\mathrm{t} & =\text { waktu }(\mathrm{s}) \\
\mathrm{h}_{1} & =\text { tinggi muka air awal }(\mathrm{mm})
\end{array}
$$

$\mathrm{h}_{2} \quad=$ tinggi muka air akhir $(\mathrm{mm})$

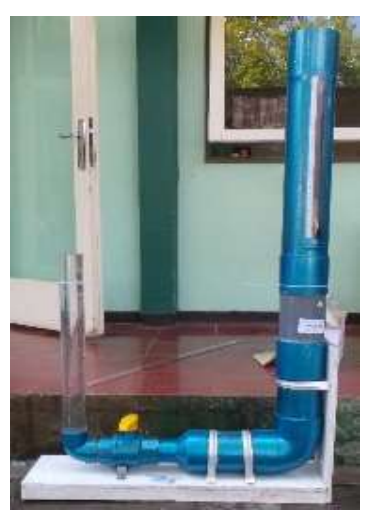

Gambar 1. Gambar Alat Falling Head

\subsubsection{Void Ratio}

Isi pori dapat ditentukan menurut ASTM C1688. Isi pori ditentukan berdasarkan prosentase total dari pori-pori oleh volume dalam sample. Isi pori dari beton berpori dihitung berdasarkan persamaan 3 .

$$
\begin{aligned}
& \text { void ratio }(\%)=\frac{T-D}{T} \times 100 \\
& \text { Dimana, } \mathrm{D}=\left(\mathrm{M}_{\mathrm{c}}-\mathrm{M}_{\mathrm{m}}\right) / \mathrm{V}_{\mathrm{m}} \text { (Density) } \\
& \mathrm{M}_{\mathrm{c}} \quad=\text { massa dari alat ukur yang diisi } \\
& \text { dengan beton } \\
& \mathrm{M}_{\mathrm{m}} \quad \text { = netto massa dari beton dengan } \\
& \text { mengurangi massa alat ukur } \\
& \mathrm{V}_{\mathrm{m}} \quad=\text { volume alat ukur } \\
& \mathrm{T}=\mathrm{Ms} / \mathrm{Vs} \\
& \text { Ms } \quad=\text { massa total dari material } \\
& \text { Vs } \quad=\text { total volume dari material }
\end{aligned}
$$

Tipikal beton porous untuk trotoar biasanya memiliki void rasio sebesar $15-22 \%$ dan dapat mengalirkan air $0,1-0,3 \mathrm{~m}^{3} /$ menit untuk melewatkan air pada suatu luasan persegi [6].

\subsubsection{Density}

Density merupakan perbandingan antara massa benda dengan volume benda. Pengujian dilakukan dengan menimbang berat benda uji dan membaginya dengan volume benda uji.

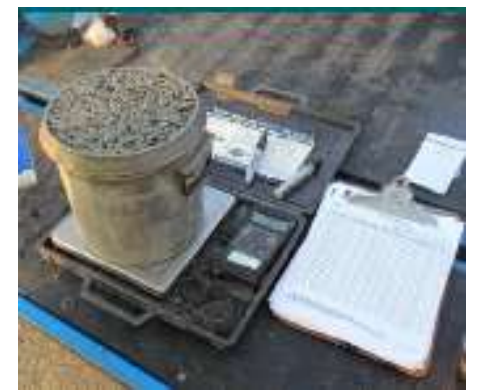

Gambar 2. Pengukuran Density Beton Segar 
Pada penelitian beton porous ini density dilakukan pada kondisi beton segar sesuai dengan aturan pada ASTM C1688M-10, yaitu dengan mengukur massa netto beton dengan mengurangi massa alat ukur, $\mathrm{M}_{\mathrm{m}}$ didapat dari massa pengukur yang telah diisi dengan beton, $\mathrm{M}_{\mathrm{c}}$. Hitung density (berat jenis), D dengan membagi massa netto dengan volume pengukur, $\mathrm{V}_{\mathrm{m}}$ yaitu sebagai berikut :

$D=\frac{M_{c}-M_{m}}{V_{m}}$

Keterangan :

D = densitas beton $\left(\mathrm{kg} / \mathrm{m}^{3}\right)$

$\mathrm{M}_{\mathrm{c}} \quad$ = massa wadah ukur yang diisi beton

$(\mathrm{kg})$

$\mathrm{M}_{\mathrm{m}} \quad=$ massa wadah ukur $(\mathrm{kg})$

$\mathrm{V}_{\mathrm{m}} \quad=$ volume wadah ukur $\left(\mathrm{m}^{3}\right)$

\subsubsection{Kuat Tekan (Compression Test)}

Kekuatan tekan adalah kemampuan beton untuk menerima gaya tekan persatuan luas. Kuat tekan beton mengidentifikasikan mutu dari sebuah struktur. Semakin tinggi kekuatan struktur dikehendaki, semakin tinggi pula mutu beton yang dihasilkan (Mulyono, 2004).

Besarnya kuat tekan dapat ditentukan dengan persamaan:

$f_{\mathcal{C}^{\prime}}=\frac{\mathrm{P}}{\mathrm{A}}$.

Keterangan :

$f c^{\prime}=$ kuat tekan beton umur rencana (Mpa)

$\mathrm{P}=$ beban uniaksial tekan maksimum $(\mathrm{N})$

$\mathrm{A}=$ luas penampang benda uji $\left(\mathrm{mm}^{2}\right)$

Rongga-rongga pada beton porous menyebabkan nilai kuat tekannya lebih rendah dibanding beton konvensional. Akan tetapi dengan menurunkan kapasitas porositasnya, beton porous dapat mencapai kuat tekan yang relatif besar. Kekuatan beton porous akan berkurang seiring dengan meningkatnya porositas, dan kekuatan tekan beton porous yang menggunakan RCA lebih rendah daripada beton porous yang menggunakan NA.

Berdasarkan ACI (American Concrete Institute) 522R-10 [4] tentang beton porous, biasanya kuat tekan beton porous sebesar 2,8 Mpa sampai 28 Mpa. Hal itu menyebabkan beton porous memiliki aplikasi yang tebatas karena kuat tekannya yang kebih kecil dibanding beton konvensional, karena itulah beton porous digunakan untuk beton non structural

Pengujian pada umur 7,14 dan 21 hari adalah agar hasil uji kuat tekan beton dapat di pantau tingkat perkembangan kenaikan kuat tekan beton secara betahap dan kuat tekan beton paling tinggi biasanya dicapai pada umur ke 28 hari. Pada penelitian ini standar yang digunakan untuk menguji kuat tekan beton porous adalah standart ASTM C-39-86.

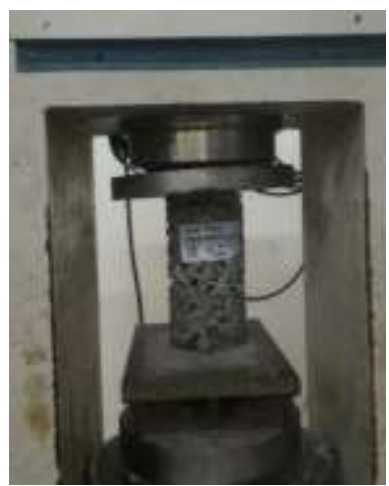

Gambar 3. Pengujian Kuat Tekan Beton

\section{METODE PENELITIAN}

Variabel yang digunakan dalam penelitian adalah sebagai berikut.

$\checkmark \quad$ Variabel kontrol :

1. FAS 0,3

2. Ukuran agregat 0,5 sampai $1 \mathrm{~cm}, 1$ sampai $2 \mathrm{~cm}$, serta 0,5 sampai $2 \mathrm{~cm}$

3. Benda uji silinder dengan diameter $100 \mathrm{~mm}$ x $200 \mathrm{~mm}$ (4" x 8")

4. Perawatan benda uji beton dibungkus plastik selama 7 hari

5. Pengujian kuat tekan dilakukan pada umur 28 hari

\section{$\checkmark \quad$ Variabel bebas :}

Penggunaan RCA dengan prosentasi komposisi berbeda yaitu $0 \%, 50 \%$, dan $100 \%$ terhadap NCA

$\checkmark$ Variabel terikat :

1. Void ratio

2. Permeabilitas

3. Kuat tekan

Metode pelaksanaan yang dilakukan berdasarkan standart yang berlaku untuk beton porous diantaranya adalah ACI 522R, penelitian pendahuluan untuk agregat yaitu ASTM C-33, density dan void ratio beton segar yaitu ASTM C1688, curing ACI 522-I-13 dan kuat tekan ASTM C-39. Metode pelaksanaan sama dengan beton biasa, namun perlu proctor hammer standart untuk pemadatan pada saat pembentukan beton pada silinder. Perbandingan antara semen, agregat, dan air adalah $1: 4: 0,3$. Curing (perawatan) beton dilakukan dengan cara menutup cetakan beton dengan plastik selama 7 hari, karena sesuai dengan pelaksanaan curing yang ada di lapangan. 
Tahapan dalam penelitian ini disusun seperti pada diagram alir pada Gambar 4.

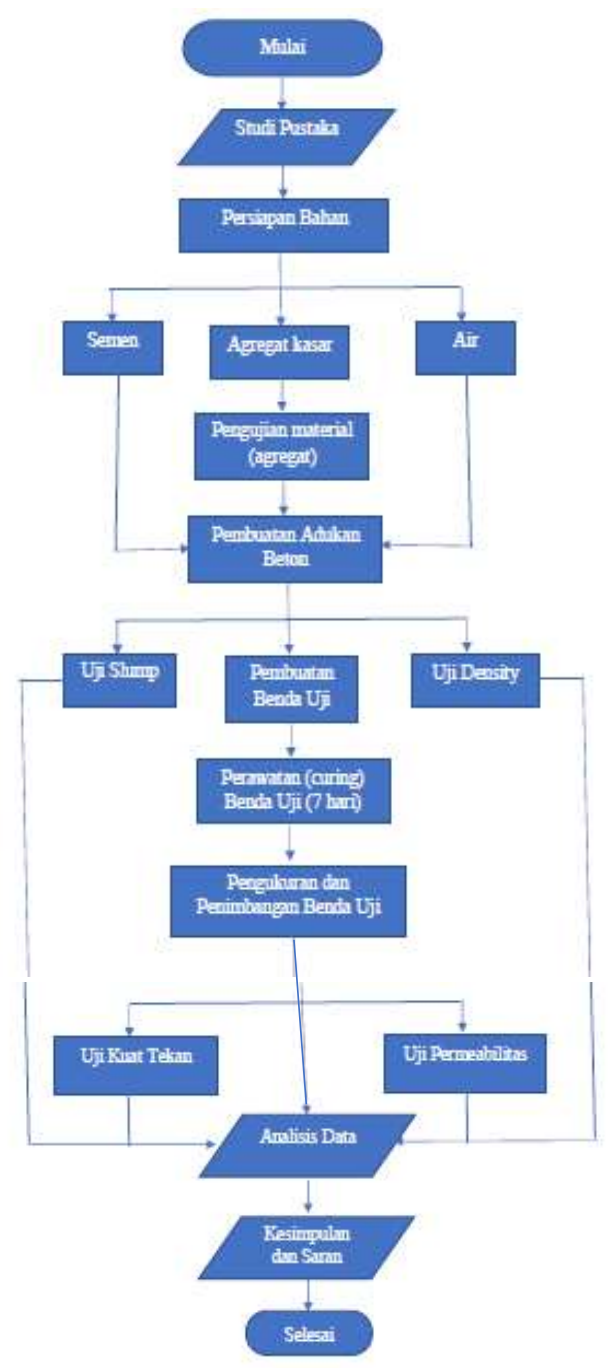

Gambar 4. Diagram Alir Penelitian

\section{PEMBAHASAN}

\subsection{Void Ratio Beton Porous}

Angka pori diperoleh dari perbandingan antara selisih berat volume teori dan berat volume aktual dengan volume aktual. Berat volume teori diperoleh dari perbadingan massa campuran dengan volume absolut total dari komponen material dalam campuran. Angka void ratio beton porous dapat dilihat pada Tabel 1. Hasil pada Tabel 1 menunjukkan beton dengan agregat dengan ukuran $1-2 \mathrm{~cm}$ kadar RCA 50\% menunjukkan angka pori yang paling besar yaitu $31.550 \%$, sedangkan beton pada ukuran agregat $0,5-1 \mathrm{~cm}$ kadar RCA $100 \%$ menunjukkan angka pori paling kecil yaitu 28.517\%. Angka pori yang besar disebabkan karena agregat yang berukuran besar sehingga mengakibatkan luas permukaan agregat yang diikat oleh pasta semen menjadi kecil. Selain itu, pengaruh berat jenis material yang mempengaruhi berat volume absolut untuk seluruh komponen. Hal ini berarti bahwa semakin rendah angka pori, semakin tinggi kepadatan betonnya, dan semakin tinggi angka pori, semakin rendah kepadatan beton dapat dilihat pada Gambar 5.

Tabel 1. Angka Pori Beton Porous

\begin{tabular}{|c|c|c|c|c|c|}
\hline No. & RCA & Size & $\mathbf{T}$ & D & $\begin{array}{c}\text { Void } \\
\text { Ratio } \\
(\%)\end{array}$ \\
\hline 1 & \multirow{3}{*}{$0 \%$} & $0.5-1$ & 1604.94 & 1258.83 & 21.565 \\
\hline 2 & & $1-2$ & 1683.21 & 1173 & 30.312 \\
\hline 3 & & $0.5-2$ & 1654.75 & 1173 & 29.113 \\
\hline 4 & \multirow{3}{*}{$50 \%$} & $0.5-1$ & 1572.92 & 1101.48 & 29.973 \\
\hline 5 & & $1-2$ & 1640.52 & 1122.94 & 31.550 \\
\hline 6 & & $0.5-2$ & 1615.62 & 1173 & 27.396 \\
\hline 7 & \multirow{3}{*}{$100 \%$} & $0.5-1$ & 1540.91 & 1101.48 & 28.517 \\
\hline 8 & & $1-2$ & 1597.83 & 1165.85 & 27.035 \\
\hline 9 & & $0.5-2$ & 1576.48 & 1108.63 & 29.677 \\
\hline
\end{tabular}

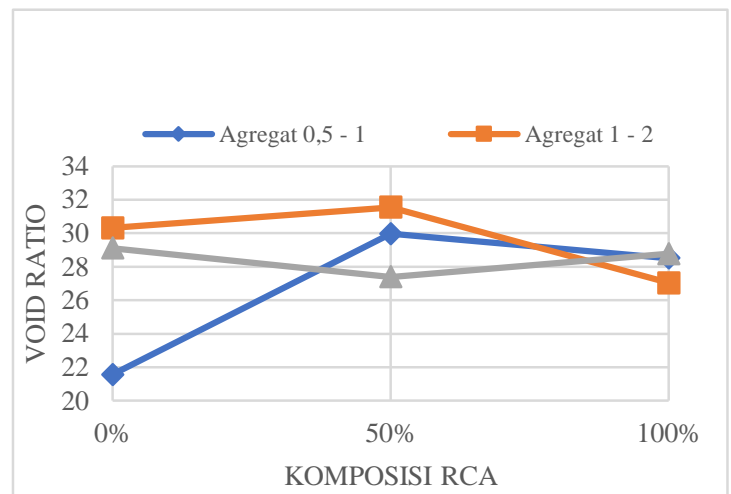

Gambar 5. Grafik Hubungan Void Ratio dan Komposisi RCA

\subsection{Permeabilitas Beton}

Nilai permeabilitas pada Tabel 2 menunjukkan bahwa beton yang paling permeable merupakan beton dengan komposisi agregat berukuran 1-2 cm dan kadar RCA sebesar $50 \%$ yaitu rata-rata sebesar 11,926 $\mathrm{mm} /$ detik, sedangkapn pada beton yang paling tidak permeable pada beton dengan komposisi 
agregat berukuran 0,5 - 1 dan kadar RCA 0\% yaitu rata-rata sebesar $5,052 \mathrm{~mm} / \mathrm{sec}$. Hal ini terjadi karena pada beton dengan agregat 1-2 dan RCA 50\%, memiliki angka prosentase pori yang besar sehingga air cepat melewati beton. Sedangkan pada permeabilitas yang kecil disebabkan karena angka prosentase pori pada variasi ini relative kecil daripada yang lain.

Tabel 2. Permeabilitas Beton Porous

\begin{tabular}{ccc}
\hline Size & \% RCA & Permeabilitas \\
\hline $0,5-1,0$ & $0 \%$ & 5.052 \\
\hline & $50 \%$ & 7.760 \\
\hline & $100 \%$ & 6.379 \\
\hline $1,0-2,0$ & $0 \%$ & 6.179 \\
\hline & $50 \%$ & 11.926 \\
\hline & $100 \%$ & 9.233 \\
\hline $0,5-2,0$ & $0 \%$ & 9.635 \\
\hline & $50 \%$ & 6.786 \\
\hline & $100 \%$ & 8.981 \\
\hline
\end{tabular}

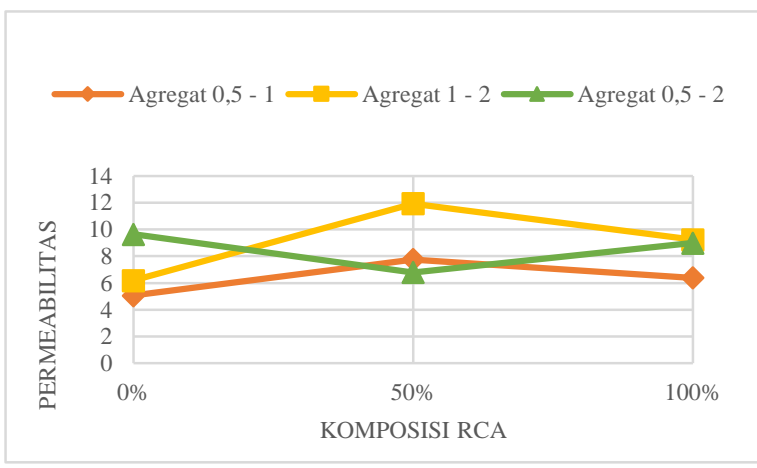

Gambar 6. Grafik Hubungan Permeabilitas dan Komposisi RCA

\subsection{Kuat Tekan Beton Porous}

Pengujian kuat tekan ini dimaksudkan untuk mengetahui pengaruh angka pori dan permeabilitas terhadap kuat tekan beton porous. Hasil pengujian ini diharapkan mendapatkan kuat tekan yang tinggi untuk mendapatkan variasi RCA yang optimal. Beton diuji pada umur 28 hari. Setiap variasi mix design dibuat tiga benda uji dengan ukuran yang sama. Hasil pengujian kuat tekan beton porous dapat dilihat pada Tabel 3.
Tabel 3. Kuat Tekan Rata-rata Silinder Beton Porous

\begin{tabular}{ccc}
\hline Size & \% RCA & $\begin{array}{c}\text { Kuat Tekan } \\
(\mathbf{M P a})\end{array}$ \\
\hline $\mathbf{0 , 5}-\mathbf{1 , 0}$ & $0 \%$ & 8.072 \\
\hline & $50 \%$ & 6.465 \\
\hline & $100 \%$ & 7.893 \\
\hline & & \\
\hline $\mathbf{1 , 0}-\mathbf{2 , 0}$ & $0 \%$ & 6.461 \\
\hline & $50 \%$ & 4.720 \\
\hline & $100 \%$ & 5.416 \\
\hline $\mathbf{0 , 5}-\mathbf{2 , 0}$ & $0 \%$ & 8.051 \\
\hline & $50 \%$ & 10.211 \\
\hline & $100 \%$ & 4.474 \\
\hline
\end{tabular}

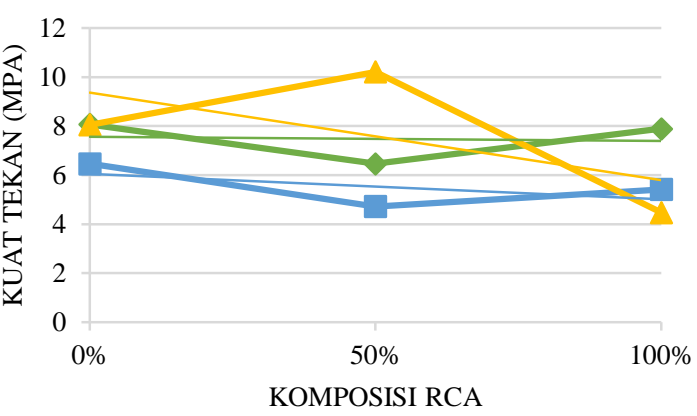

Gambar 7. Grafik Uji Kuat Tekan terhadap Komposisi RCA

Pada Tabel 3 merupakan hasil uji kuat tekan rata-rata pada setiap variasi mix design. Nilai kuat tekan di atas menunjukkan bahwa agregat dengan ukuran $0,5-2 \mathrm{~cm}$ dengan variasi RCA 50\% memiliki nilai kuat tekan yang tinggi yaitu sebesar 10,211 MPa hasil kuat tekan terendah pada variasi mix design RCA $100 \%$ dengan ukuran $0,5-2 \mathrm{~cm}$ yaitu sebesar 4,474 Mpa. Kenaikan dan penurunan kuat tekan juga dapat dilihat pada Gambar 7.

\subsection{Hubungan Void Ratio, dan Permeabilitas terhadap Kuat Tekan}

Hubungan data void ratio dan permeabilitas terhadap kuat tekan merupaka tujuan dari penelitian ini dibuat untuk mendapatkan kadar RCA dan ukuran agregat yang akan dipakai untuk mencapai hasil yang 
Tabel 4. Data Kuat Tekan, Void Ratio, Berat Volume, dan Permeabilitas Beton Porous

\begin{tabular}{cccccc}
\hline Size & RCA & Kuat Tekan & Void Ratio & Berat Volume & Permeabilitas \\
\hline & & Mpa & $\%$ & $\mathrm{~kg} / \mathrm{m} 3$ & $\mathrm{~mm} / \mathrm{det}$ \\
\hline $\mathbf{0 , 5} \mathbf{- 1 , 0}$ & $0 \%$ & 8.072 & 21.565 & 1258.833 & 5.052 \\
\cline { 2 - 6 } & $50 \%$ & 6.465 & 29.973 & 1173.003 & 7.760 \\
\cline { 2 - 6 } & $100 \%$ & 7.893 & 28.517 & 1173.003 & 6.379 \\
\hline $\mathbf{1 , 0 - 2 , 0}$ & $0 \%$ & 6.461 & 30.312 & 1101.479 & 6.179 \\
\cline { 2 - 6 } & $50 \%$ & 4.720 & 31.550 & 1122.936 & 11.926 \\
\cline { 2 - 6 } & $100 \%$ & 5.416 & 27.035 & 1173.003 & 9.233 \\
\hline $\mathbf{0 , 5 - 2 , 0}$ & $0 \%$ & 8.051 & 29.113 & 1101.479 & 9.635 \\
& $50 \%$ & 10.211 & 27.396 & 1165.851 & 6.786 \\
\cline { 2 - 6 } & $100 \%$ & 4.474 & 28.770 & 1108.631 & 8.981 \\
\hline
\end{tabular}

optimum. Hasil pengujian kuat tekan, angka pori, berat volume, dan permeabilitas dapat dilihat pada Tabel 4.

Berdasarkan Tabel 4 menunjukkan bahwa pada variasi agregat ukuran $0,5-1,0$ kuat tekan tertinggi terdapat pada RCA $0 \%$ yaitu sebesar $8,072 \mathrm{MPa}$, dimana angka pori kecil yaitu $21,565 \%$, dan permeabilitas kecil yaitu 5,052 $\mathrm{mm} /$ det.begitu pula dengan void ratio dan permeabilita yang paling yaitu sebesar $29,973 \%$; dan $7,76 \mathrm{~mm} /$ det memiliki nilai kuat tekan yang relative rendah yaitu $6,465 \mathrm{MPa}$. Kuat tekan beton porous berbanding terbalik terhadap prosentase angka pori dan permeabilitas. Hal ini sangat memungkinkan karena pada kondisi poripori yang besar, gesekan antar agregat juga akan semakin besar, ikatan antar agregat semakin lemah, maka dari itu kuat tekan pada kondisi ini turun. Hubungan antara void ratio, permeabilitas, dan kuat tekan dapat dilihat pada Gambar 8 dan Gambar 9.

Berdasarkan Gambar 8 dan Gambar 9 dapat disimpulkan bahwa semakin besar void ratio, maka semakin kecil nilai kuat tekan beton porous dan semakin besar permeabilitas nilai kuat tekan juga semakin turun.

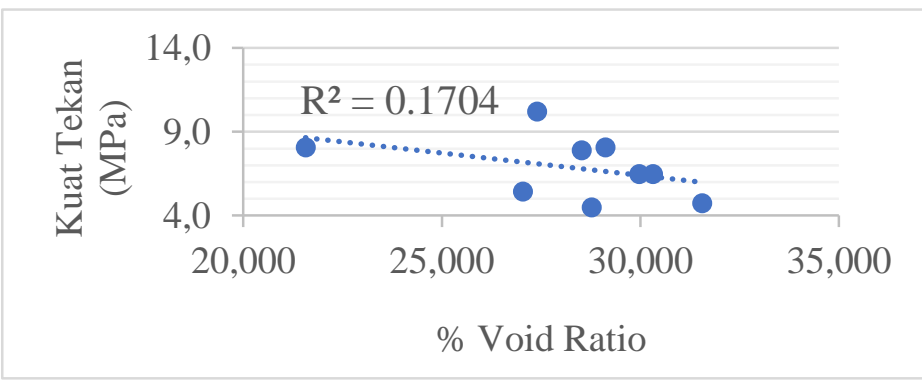

Gambar 8. Hubungan Kuat Tekan dan Void Ratio

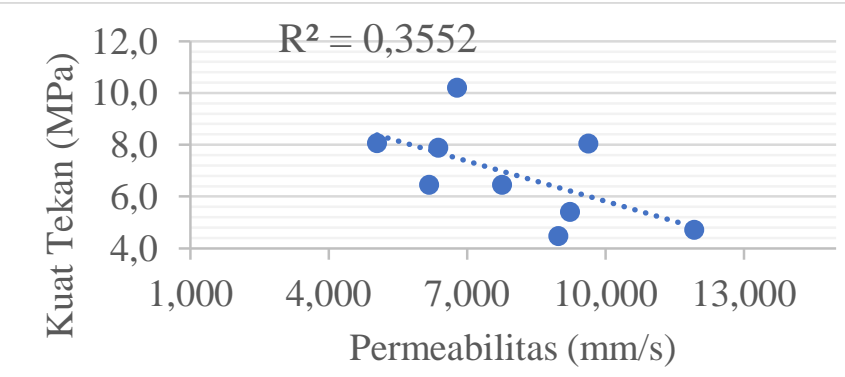

Gambar 9. Hubungan Permeabilitas dan Kuat Tekan 


\section{KESIMPULAN DAN SARAN}

\subsection{Kesimpulan}

Berdasarkan hasil penelitian dan pembahasan yang telah dilakukan maka didapatkan kesimpulan sebagai berikut :

1. Variasi RCA mempengaruhi kuat tekan beton porous. Semakin besar kadar RCA dalam beton, kuat tekan beton semakin menurun. Hal ini disebabkan karena RCA mengandung mortar, yang mengakibatkan absorbsi agregat meningkat serta mudah retak. Pada kondisi RCA 100\% kuat tekan lebih rendah daripada RCA $0 \%$ kadar agregat alami yang memiliki butiran lebih padat daripada RCA menyebabkan kuat tekan relatif lebih tinggi.

2. Semakin tinggi void ratio pada beton porous menyebabkan permeabilitas semakin tinggi, begitu pula kondisi sebaliknya. Sedangkan semakin tinggi void ratio dan permeabilitas, menyebabkan kuat tekan semakin rendah. Void ratio menunjukkan bahwa beton memiliki banyak rongga, dan apabila beton memiliki banyak rongga, maka beton tersebut sangat mudah dilalui oleh air (permeable). Pada penelitian ini, void ratio dan permeabilitas tertinggi ada pada kondisi mix design $50 \%$ RCA ukuran $1-2 \mathrm{~cm}$, dimana juga menghasilkan nilai permeabilitas tertinggi yaitu $11,926 \mathrm{~mm} /$ det. Maka dari itu nilai kuat tekan memiliki nilai yang relative kecil yaitu 4,72 MPa.

3. Kondisi paling optimal pada dasarnya terdapat pada kondisi 0\% RCA, karena kandungan agregat alami yang kuat. Namun, penelitian ini menunjukkan bahwa kuat tekan rata-rata tertinggi pada kondisi $50 \%$ RCA dengan ukuran agregat $0,5-2,0 \mathrm{~cm}$ beton porous yaitu sebesar 10,211 MPa. Nilai tersebut didapatkan dari variasi beton dengan nilai angka pori $27,396 \%$ serta permeabilitas 6,786 $\mathrm{mm} /$ det. Hal ini dipengaruhi oleh berat jenis dari agregat itu sendiri, serta kualitas agregat.

\subsection{Saran}

Pada penelitian yang dilaksanakan untuk pengaruh void ratio dan permeabilitas terhadap kuat beton dengan variasi RCA, dapat diberikan saran sebagai berikut :

1. Tempat penyimpanan benda uji harus terhindar dari kegiatan yang dapat merusakbenda uji mengingat jumlah benda uji untuk setiap variasi sedikit.

2. Dapat dilanjutkan untuk penelitian selanjutnya dengan uji tes yang berbeda seperti uji abrasi, uji kuat lentur, perkuatan beton porous dengan penambahan faber, dan lain sebagainya dengan pertimbangan dosen dan penelitian yang sudah ada.

\section{DAFTAR PUSTAKA}

[1] Mc Govern M. "Recycled Aggregate for reinforced concrete". Concrete Technology today. PCA (Portland Cement Association). Vol. 23, No. 2. July. 2002.

[2] Harber, P. J. Applicability of No Fines Concrete as a Road Pavement. Southern Queensland, University of Southern Queensland Faculty of Engineering and Surveying.2005

[3] Neville, A. M. Properties of Concret,. New York: John Wiley and Sons Inc. 1995.

[4] ACI Commmittee 522. Pervious concrete, ACI International, Farmington Hills. 2006.

[5]Joshi, Tejas dan Dave, Urmil. Evaluation of Strength, Permeability and Void Ratio of Previous Concrete with Changing w/c Ratio and Aggregate Size. Volume 7, Issue 4. Gujarat: Nirma University, India. 2016.

[6] Shinde, G. U. dan Vallunjkar, S. S. An Experimental Study on Compressive Strength, Void Ratio and Infiltration Rate of Pervious Concrete. Volume: 4 Issue: 04. Karad: Government College of Engineering, India.2015. 